\title{
ANALYSIS OF THE SPECIFIC COMMON COMPETENCES OF THE DEGREE COURSES IN SPEECH THERAPY AND ON THE ABILITY TO APPLY IN THE DIDACTIC SYSTEMS
}

\author{
${ }^{1}$ Paterniti Maria Rosa, ${ }^{2}$ Bua Alberto, ${ }^{3}$ La Tona Federico, ${ }^{4}$ Vitale Chiara \\ ${ }^{1}$ Logopedista - Docente di Scienze Logopediche Applicate II -C.I. -Logopedia nei disturbi specifici e dell'apprendimento \\ (modulo), Università degli Studi di Palermo - Presidente Commissione d'Albo Logopedisti Palermo (ordine tsrm e \\ pstrp di palermo) \\ ${ }^{2}$ Logopedista - Segretario Commissione d'Albo Logopedisti Palermo (ordine tsrm e pstrp di palermo) \\ ${ }^{3}$ Logopedista - Componente Commissione d'Albo Logopedisti Palermo (ordine tsrm e pstrp di palermo) \\ ${ }^{4}$ Logopedista
}

KEYWORDS: Skills, Speech Therapy, University

\section{ABSTRACT}

This article, taken from the ending research thesis of the studies in Business Administration in Pegaso University, derives from the lack of detailed data on colon-rectal cancer in Apulia, in 2019. The clinical, economic and statistical study introduced has given the possibility to examine the neoplasia incidence in Apulia reality, to estimate for the first time the Lars major phenomenon (Low Anterior Resection Syndrome) after a rectum surgical treatment These goals have been achieved starting from the national data analysis provided by Airtum and Aiom; and operating through benchmarking, among the most virtuous Italian realities, it has been possible to estimate the forecast of refundability of health services generated by the treatment of colon cancers, rectal cancers and of the Lars phenomenon management. We can see the incidence of 2,802 total cases of colon-rectal cancer so divided: 1,920 colon cancer cases and 882 rectal cancer cases. The Lars phenomenon, according to the most recent medical literature, presents 444 cases, considering that $90 \%$ of the 882 rectum tumors will have a surgery; $56 \%$ of these develops Lars major. Assuming to treat all cases of Lars major, it would potentially be possible a refundability of 63,492 Euros. While, as regards the refundability obtained from the treatment of the 2,802 colon-rectal cancer total cases, it could be hypothesized a total refundability of 18,897,408 Euros.

\section{INTRODUCTION}

Law 11 January 2018 n. 3 has reformed orders and colleges of health professions instituting the Order of health technicians in Radiology and health techniques, rehabilitation and prevention, and inside the Albi of health techniques, the rehabilitates tion and prevention. The law n. $3 / 2018$ provides for a new definition of the Orders : "non-economic public bodies that act as subsidiary bodies of the State". The traditional meaning of "auxiliary body" is thus overcome, assigning important Orders to the Orders:

- protect public interests related to professional practice;

- to promote and ensure the independence, autonomy and responsibility of professionals in professional practice;

- guarantee technical-professional quality, enhance the social function of the professions and safeguard human rights and ethical principles of professional practice (indicated in the respective codes of ethics);

- guarantee the protection of individual and collective health.

In particular, the new regulation provides for a renewal of the Orders of the health professions, adapting the reference legislation to the Orders supervised by the Ministry of Health with reference to their internal functioning and changing the name of the college in order. Other assignments assigned to these entities include keeping the registers of their respective professions, verifying the possession of qualifications for professional practice, evaluating continuing education activities, expanding the codes of ethics, transparency of communication, the establishment of specific disciplinary bodies. The issuing of the aforementioned law brings to the attention of all health professions the need to guarantee citizens an increasingly transparent, competent and qualified action, but also the need to protect their professional specificity. The same law delegates to the Government provisions for the reorganization of the health professions and for the health management of the Ministry of Health, placing the attention of the Health Professions on the specific specific competences and on the application skills of the same, which must be evident in the educational systems to protection of the profession. "Competence" is defined as the set of individual characteristics that contribute to the effective supervision of a working situation, a service, an activity. We can also define it as the ability to use personal knowledge, skills and abilities, in work, study and personal development situations. As part of the internship of the Master's Degree Course in "Rehabilitation Sciences of Health Professions", carried out at the University of Palermo in the 2017/2018 academic year, we conducted research on the skills of the speech therapist in degree from Italian universities. These skills have been sought in the SUA[8] files , available on the Universitaly [9] portal, 
of the various Degree Courses (CDL). There are currently 37 Degree Courses in Speech Therapy in Italy: 11 in Northern Italy, 8 in Southern Italy and 8 in Central Italy. The purpose of this work is to identify which skills are always present and which instead become "specific" for our profession.

\section{METHODS AND MATERIALS}

Research was carried out on the specific common skills of the CDL in Speech Therapy, using the portal of the Ministry of Education, University and Research called "Universitaly" and evaluating the SUA cards of the various degree courses. The portal is aimed at high school students and their families for a conscious choice of university courses, for university students who intend to continue their studies, for high schools who want to monitor their teaching and to the universities themselves in order to detail their own. training offer. The Single Annual Form (SUA) is a functional management tool for the planning, implementation, self-assessment and re-design of the Degree Program. The SUA form is the main tool of the AVA system (Self-assessment - Periodic evaluation - Accreditation) introduced by Law 240/2010, by Legislative Decree 19/2012 and implemented by DDMM 47/2013, 1059/2013 and 987/2016. In this sense, the Single Annual Study Program Card aims to:

- define the demand for training;

- describe the training plan and learning environment;

- certify learning outcomes;

- clarify roles and responsibilities relating to the management of the University's Quality Assurance system;

- periodically review the structure of the Degree Course and its effects to make the necessary changes.

SUA CdS is one of the reference tools in the study course self-evaluation and evaluation process. SUA cards have a standard structure, in fact there are numerous panels or each of which deals with a specific area. Specifically, the annual SUA- CdS is divided into two sections: Administration and Quality.

The "Administration" section in which all the institution data (RAD) and course activation are automatically incorporated. In general, the panels identified with the wording "RAD" are part of the didactic system in force of the Study Program and therefore are accessible only in the event of changes in the system. The "Quality" section is made up of the following parts:

- Objectives of the Study Program (CdS): the frameworks of this section (A1, A2, A3, A4, A5) describe the training objectives that the Study Program aims to achieve through the design and implementation of the Course, defining the demand for training and the expected learning outcomes. This section answers the question "What is the CdS aiming for?";

- Student experience: the paintings in this section (B1, B2, B3, B4, B5, B6, B7) describe the student experience: the Study Plan offered, the temporal scan of the teaching and learning activities, the learning environment, or the 5 human resources and infrastructures made available. This section answers the following question "How is the stu- dy course carried out?". Here are also collected the results of the survey on the effectiveness of the Study Course perceived in itinere by students and on the overall effectiveness perceived by graduates;

- Results of the training : pictures $\mathrm{C} 1, \mathrm{C} 2, \mathrm{C} 3 \mathrm{de}-$ scribe the results of the students in their quantitative aspects - entry and course data and exit - and the effectiveness of the studies for the purpose of entering the professional world. This section answers the question: "To what extent have the proposed objectives been achieved?";

- Quality organization and management (panels D1, D2, D3, D4): this is a section of a confidential nature accessible only to those authorized by the system such as, for example, experts during the period in which they were entrusted with a evaluation or accreditation mandate of the CdS .

In light of the objective of the following work, we have focused attention in particular on paintings A4.a, A4.b.1, A4.b.2. In fact, with the exception of some cases, the competences are reported in these boxes. Every health professional, regardless of the discipline he deals with, has specific areas of competence, defined by the National Professional Profile (Ministerial Decree 14 September 1994, n.742). These include:

- basic skills: the skills that all professionals must possess when entering the world of work: English, IT, business organization, labor law;

- transversal skills: these are the communication and relational skills that every professional should possess in any professional sector and which he acquires during his life in contexts of formal, nonformal and informal education. These concern the management, innovative and relational area;

- technical-professional skills: these are the distinctive skills identified by different functions based on the professional figure they characterize;

- transversal technical-professional skills: iden tify the functions that describe the skills common to each healthcare professional and include management, training, research and consultancy.

The basic, transversal and transversal professional skills are common to the Healthcare area. The transversal technical-professional skills are specific to each profession. The technical-professional skills of the Speech Therapist, taken into consideration, are taken from the website of the Italian Speech Therapist Federation (FLI)[10]. It should also be noted that the SUACds sheets are the only tool that allows us to know the characteristics of a Degree Course, so if a competence is absent it means that this competence is not expressed in the SUA form of that Degree Course.

\section{Criteria used for the analysis of SUA- CdS cards}

The competences taken into consideration have been labeled as: present, partially (present) or absent in reference to the reply with the SUA files.

- A skill is recognized as present in an SUA form if all its sub-areas are addressed or if most of the sub-areas are addressed (generally half plus one);

- A skill is recognized partially present in an SUA form if half of its sub-areas are addressed or if the topic in question is expressed in a framework different from the frameworks A4.a and A4.b;

- A skill is recognized as absent in an SUA form if the area is not fully addressed or only a sub-area of the topic is addressed; 


\section{COMPETENZE DI BASE}

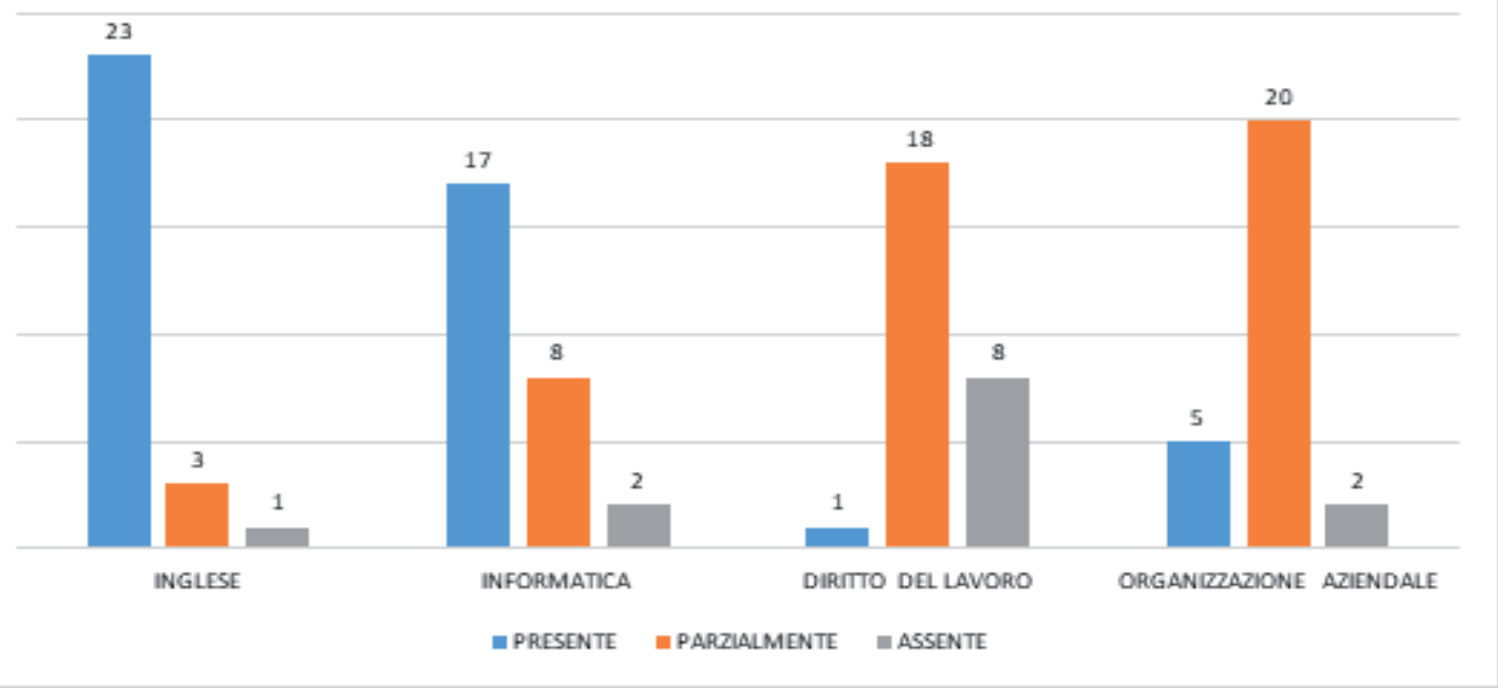

Graph 1 - Analysis of data relating to Basic Skills.

- It has been reported whether any competence that is absent is expressed in the study plan;

- It has been reported if a skill is expressed in panels other than A4.a and A4.b.

While for some cases it was very easy to attribute the labels, for others it was necessary to have a more meticulous analysis as each competence has various subareas.

\section{RESULTS AND DISCUSSION}

The scores attributed for the assessment of skills were assigned on the basis of the training objectives that the CdL proposes through the SUA form as specified below:

- 1 : present and well-defined competence;

- 0.5 : partially defined competence and / or topic present in a framework other than A4.a and A4.b;

- $\quad \mathbf{0}$ : no competence .

From the analysis of the data relating to basic skills, in terms of specific training objectives present within the training courses of Italian universities that in their tea- ching provided contain the Degree Course in Speech Therapy, it emerged that:

- $87.2 \%$ of the Degrees allow their students to develop adequate knowledge and use of the English language;

- $63 \%$ of the Degrees leads to the achievement of good IT skills;

- $66.7 \%$ of the Degrees do not adequately define the acquisition of knowledge in the field of labor law among their educational objectives (although the subject "Occupational Medicine" is included in the study plans);

- $18.5 \%$ of the Degrees allow students to develop skills in business organization.

The analysis of the data relating to transversal skills showed that:

- the skills of managerial type are represented in $74.1 \%$ of the USA sheets degree in Speech therapy in Italy;

- the innovative and creative skills are evident in $100 \%$ of the Degrees, as well as the communicative-relational ones.

\section{COMPETENZE TRASVERSALI}

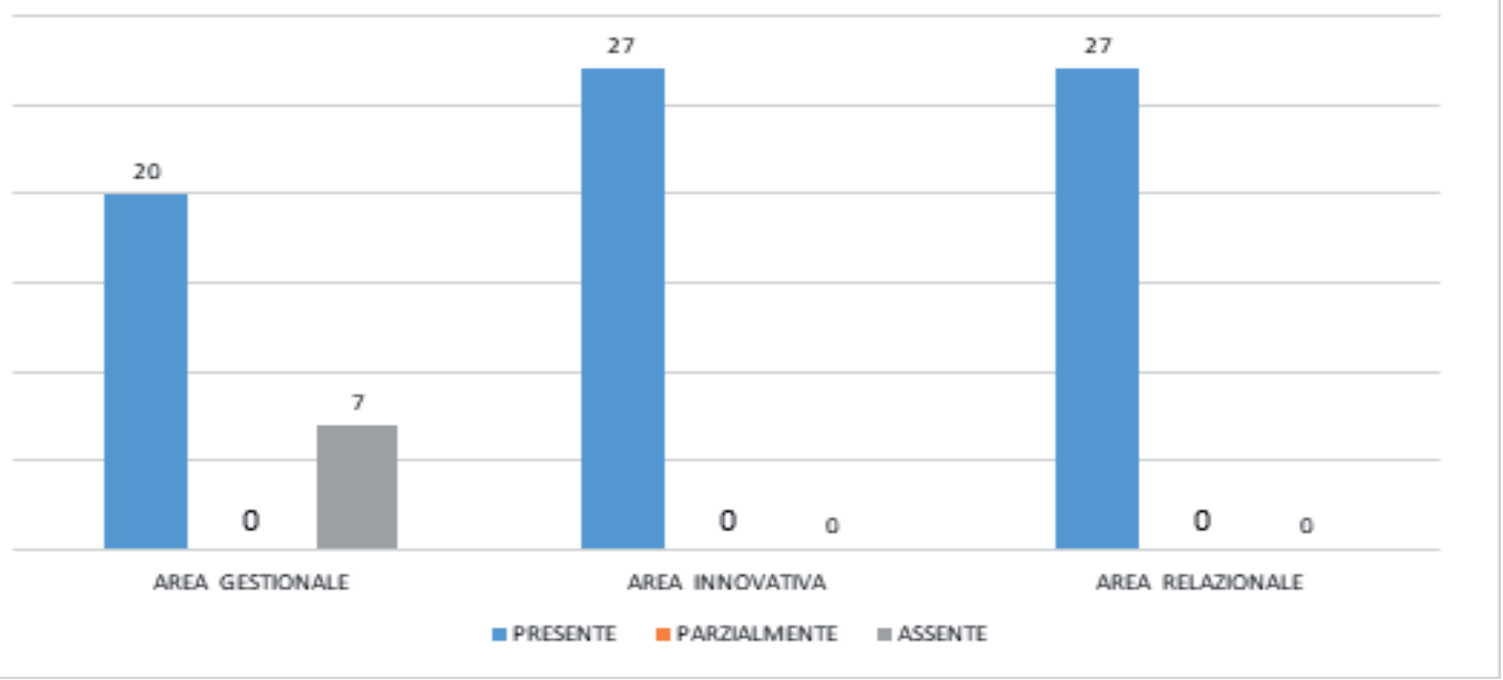

Graph 2 - Analysis of the data relating to the Transversal Competences. 


\section{COMPETENZE TECNICO - PROFESSIONALI TRASVERSALI}

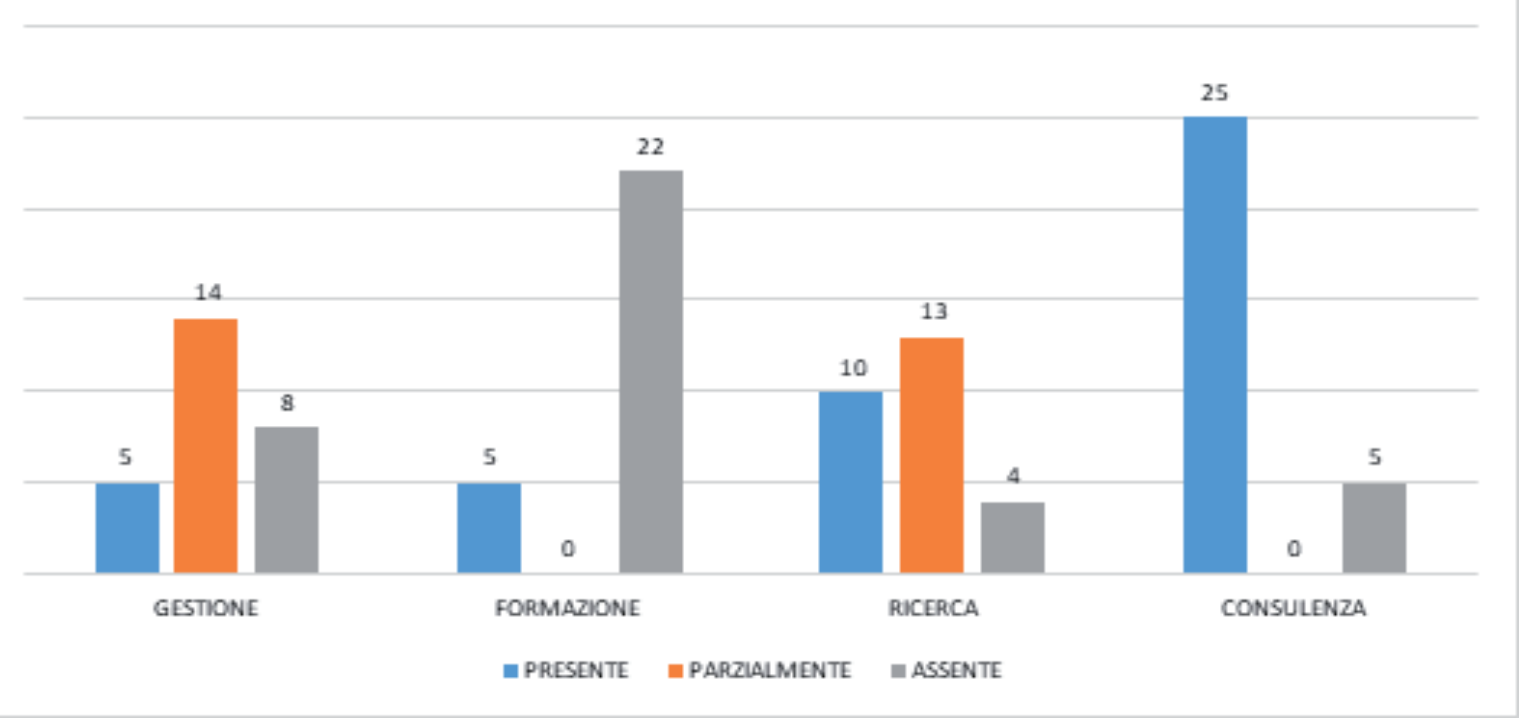

Graph 3 - Analysis of data relating to the Technical-Professional Transversal Competences.

The analysis of the data relating to the transversal technical-professional skills revealed that:

- $18.5 \%$ of the Degrees allow their students to develop health management skills;

- $18.5 \%$ of the Degrees define the acquisition of knowledge on training among their training objectives;

- $37 \%$ of the Degrees train students to research (this area of competence is only partially represented in most of the USA);

- $\quad$ as many as $92.6 \%$ of the Degrees leads to the acquisition of adequate consultancy skills .

The analysis of the data of the Speech Therapist's technical-professional skills must be distinguished in its four macro areas such as:

- $\quad$ speech therapy assessment and report;

- care and rehabilitation;
- prevention;

- therapeutic education.

There are four sub-areas within the "Speech Therapy Assessment and Report" area, namely:

1. to acquire objective and subjective information for the identification of the rehabilitative needs of the person and the community;

2. formulate therapeutic objectives referable to the speech therapy clinic;

3. evaluate the socio-environmental context;

4. to enable and rehabilitate pathologies of the voice, word, oral and written language, communicative and cognitive disabilities and oral functions.

Among these, in all the SUA cards of the CDL in Logopedia of the Italian Universities, the skills related to knowing how to evaluate the socio-environmental

\section{COMPETENZE TECNICO - PROFESSIONALI SPECIFICHE VALUTAZIONE E BILANCIO LOGOPEDICO}

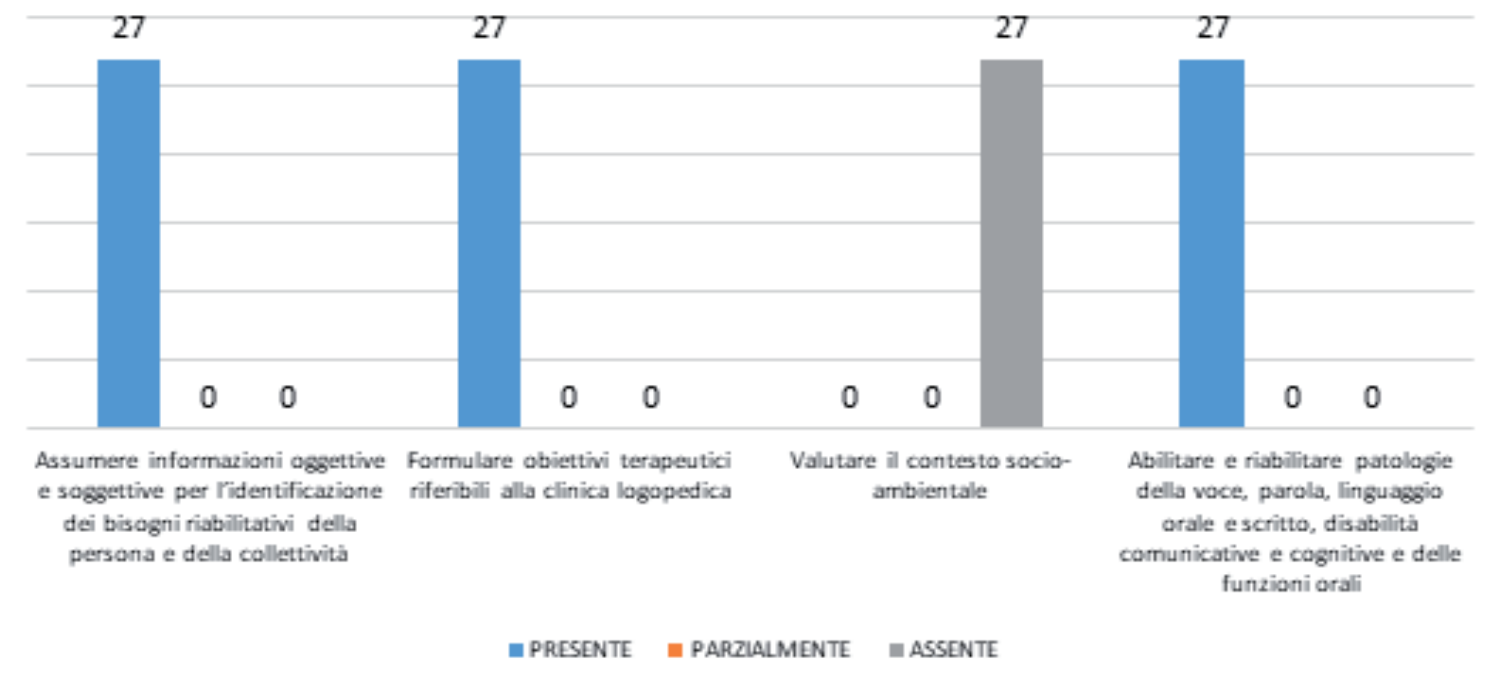

Graph 4 - Analysis of data relating to Technical-Professional Skills Specifications: evaluation and speech therapy budget 


\section{DEFINIRE IL PROGRAMMA \\ RIABILITATIVO}

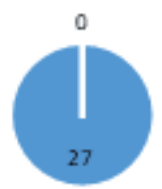

- PRESENTE = PARZLALMENTE = ASSENTE

Graph 5 - Analysis of data relating to the Technical - Professional Skills: perform the rehabilitation intervention

\section{ESEGUIRE L'INTERVENTO RIABILITATIVO}

= PRESENTE $=$ PARZIALMENTE $~=$ ASSENTE

Graph 7 - Analysis of the data relating to the Technical - Professional Skills: perform the rehabilitation intervention

\section{VERIFICARE L'EFFICACIA DELL'INTERVENTO}

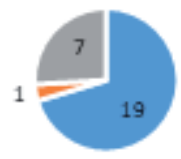

- PRESENTE = PARZLLLMENTE = ASSENTE

Graph 6 - Analysis of the data relating to the Technical - Professional Skills: verify the effectiveness of the intervention

\section{AFFRONTARE LE SITUAZIONI CRITICHE}

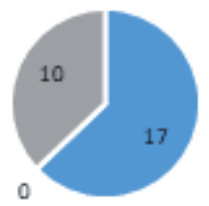

" PRESENTE = PARZLLLMENTE " ASSENTE

Graph 8 - Analysis of data relating to Technical-Professional Skills Specific: dealing with critical situations context are not present. The uniformity of this outcome offers numerous food for thought, as this competence is very important for adequately planning the rehabilitation intervention.

The macro area of "Care and Rehabilitation " also has various sub-areas, such as:

1. define the rehabilitation program;

2. carry out the rehabilitation intervention;

3. occurs King effectiveness dell'intervent or ;

4. dealing with critical situations.
The skills related to defining and carrying out the rehabilitation intervention emerge in all the SUA cards of the Degrees of the Italian Universities. On the other hand, there are anomalies for the other two subareas: the skills related to the ability to verify the effectiveness of the rehabilitation intervention are present in the vast majority of the CDL, with the exception of the CDL of Bari, Ferrara, Messina, Naples, Pisa, Verona and the Catholic University of Rome where this competence is absent. While this competence partially emerges in the SUA form of the Ferrara CDL. As for

\section{COMPETENZE TECNICO - PROFESSIONALI SPECIFICHE PREVENZIONE}

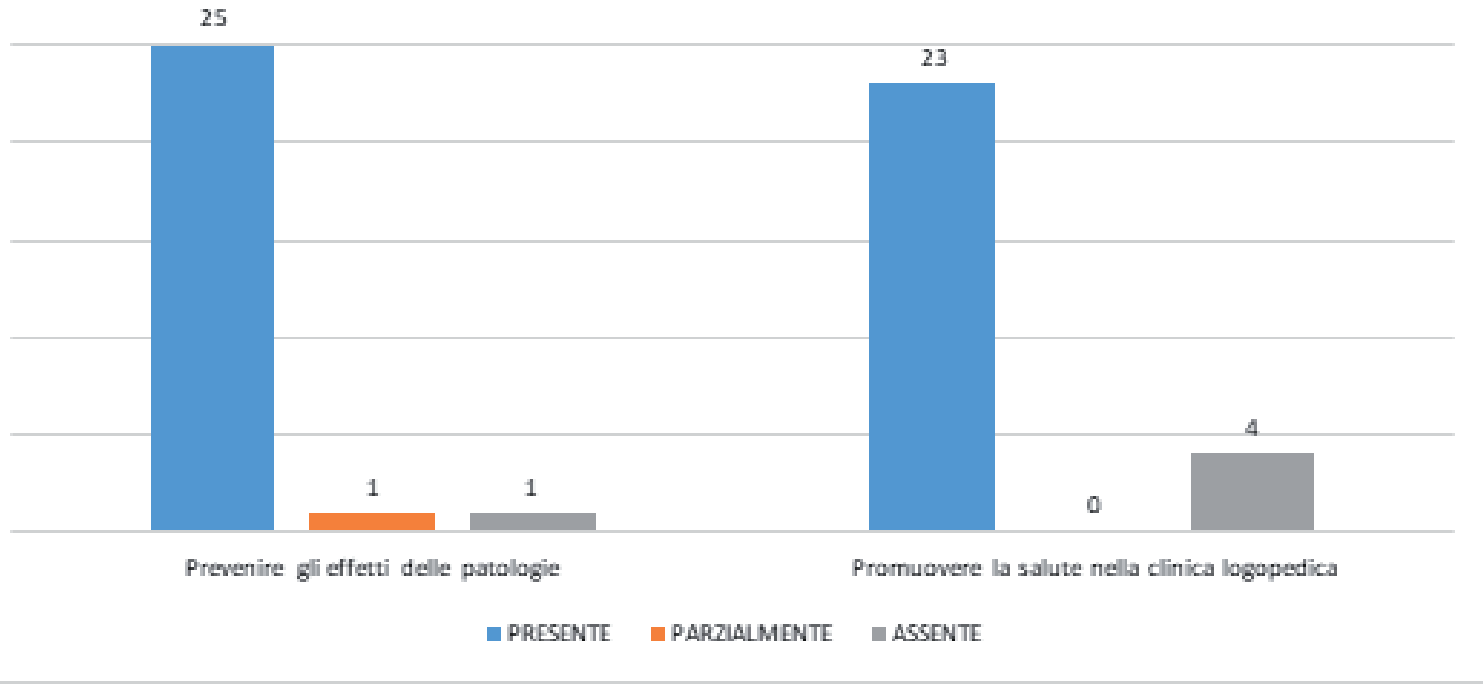

Graph 9 - Analysis of data relating to Technical-Professional Skills Specific: Prevention 


\section{COMPETENZE TECNICO PROFESSIONALI SPECIFICHE EDUCAZIONE TERAPEUTICA}

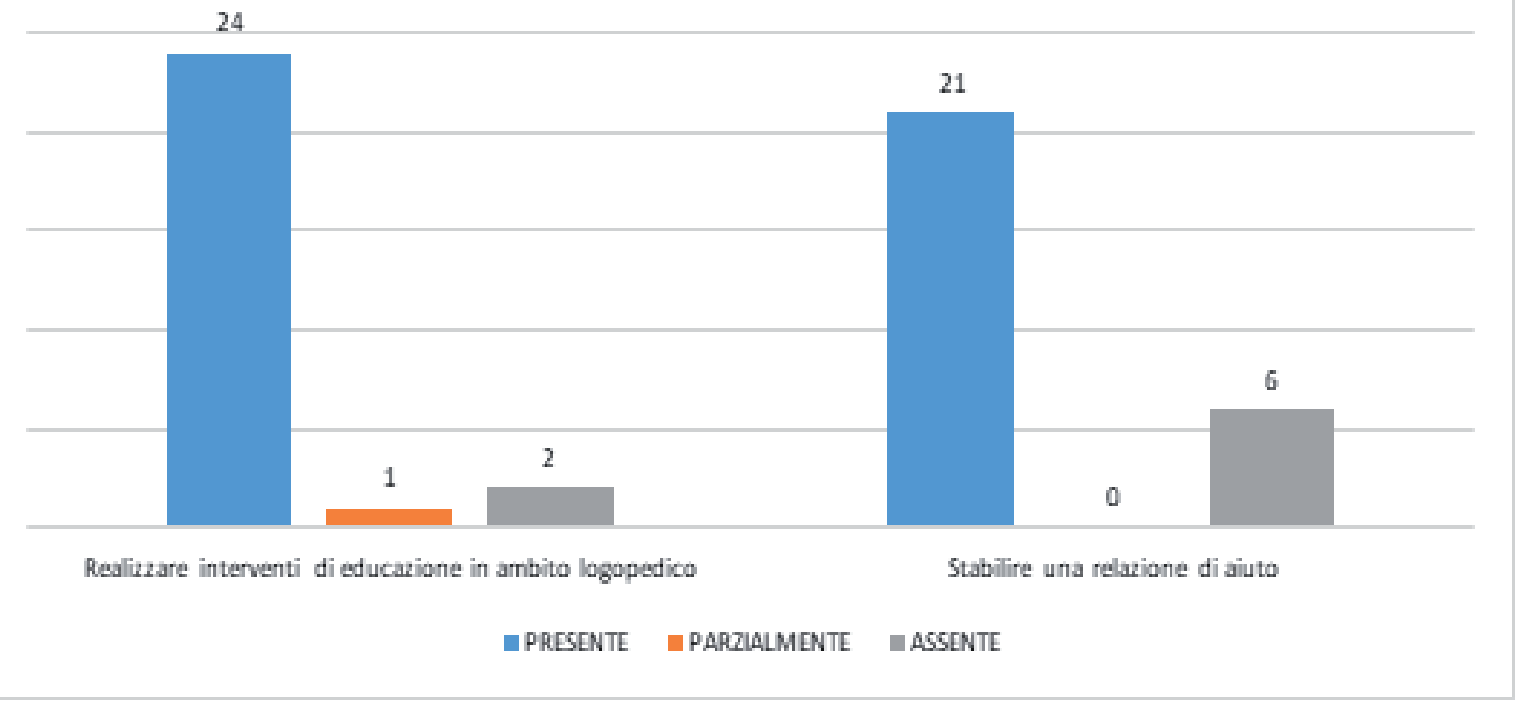

Graph 10 - Analysis of data relating to Technical-Professional Skills Specific: Therapeutic Education

the ability to deal with critical situations , this is present in most CDLs.

The graphs representing the results of the analysis carried out in relation to the specific technical and technical skills of the "Care and Rehabilitation " macro area are shown below .

There are two sub-areas within the "Prevention" area:

1. health promotion in the speech therapy clinic;

2. prevention of pathologies pertaining to the Speech Therapist (pathologies of voice, language, communication, cognitive and oral function disabilities). The skills related to the prevention of speech-related pathologies are present in almost all the SUA cards of the CDL in Logopedics, while the skills related to health promotion in the speech therapy clinic are present in most of the SUA cards, with the sole exception of the CDL of Catania, Catanzaro, Padua and Rome La Sapienza in which it is absent.

The last area of technical-professional skills concerns "therapeutic education". Therapeutic education includes two sub-areas:

1. carry out educational interventions in the speech therapy field;

2. establish a helping relationship;

It's possible to say that, globally, the skills related to the implementation of education interventions in the speech therapy field are present in almost all SUA files. While the skills related to the ability to establish a helping relationship is absent only in the CDL in Speech Therapy of the Universities of Campania, Cattolica of Rome, Naples, Pavia, Pisa and Siena.
Analysis of the data relating to specific technical-professional skills revealed that:

- In the "Evaluation and balance" area: $100 \%$ of the study CDL allows its students to develop the ability to carry out observations, evaluations, screening, counseling and speech therapy balances for the specific nosological field (pathologies of the voice, speech, oral and written language, oral functions, communicative and cognitive disabilities); however, no course takes into consideration the ability to evaluate the socio-environmental context in which the assisted person is included among its training objectives.

- In the "Care and rehabilitation" area: $100 \%$ of the LADs train students to plan and implement an enabling / rehabilitative intervention; $70.4 \%$ of the CDL include among their educational objectives the ability to verify the effectiveness of the speech therapy intervention implemented, while $63 \%$ of the courses include the ability to deal with crisis situations.

- In the "Prevention" area: $92.6 \%$ of the CDL allows students to acquire the ability to operate in a preventive perspective and, $85.2 \%$ of the CDL allows their students to promote the health of the disabled.

- In the area of "Therapeutic Education": 88.9\% of the CDL include the ability to implement educational interventions among their educational objectives, while $77.8 \%$ also includes the ability to establish a helping relationship.

The tables containing the results of the different competences are shown below. 


\begin{tabular}{|c|c|c|c|c|}
\hline BASIC SKILLS & ENGLISH & $\begin{array}{c}\text { COMPUTER } \\
\text { TECHNOLOGY }\end{array}$ & $\begin{array}{l}\text { LABOR } \\
\text { LAW }\end{array}$ & $\begin{array}{c}\text { BUSINESS } \\
\text { ORGANIZATION }\end{array}$ \\
\hline University of Bari & 1 & 1 & 0 & 0.5 \\
\hline University of Bologna & 1 & 1 & 1 & 0.5 \\
\hline University of Cagliari & 0 & 0 & 0 & 0.5 \\
\hline University of Campania & 1 & 1 & 0 & 0.5 \\
\hline University of Catania & 1 & 1 & 0.5 & 0.5 \\
\hline University of Catanzaro & 1 & 1 & 0 & 0.5 \\
\hline University of Cattolica (Rome) & 1 & 0.5 & 0.5 & 0.5 \\
\hline University of Ferrara & 1 & 1 & 0.5 & 0.5 \\
\hline University of Florence & 1 & 1 & 0.5 & 0.5 \\
\hline University of Genoa & 1 & 1 & 0.5 & 1 \\
\hline University of Marche & 1 & 0.5 & 0.5 & 0.5 \\
\hline University of Messina & 1 & 0.5 & 0 & 0.5 \\
\hline University of Milan & 1 & 1 & 0 & 1 \\
\hline $\begin{array}{l}\text { University of Modena } \\
\text { and Reggio Emilia }\end{array}$ & 0.5 & 1 & 0.5 & 1 \\
\hline University of Naples & 1 & 1 & 0.5 & 0.5 \\
\hline University of Padua & 1 & 0.5 & 0.5 & 0.5 \\
\hline University of Palermo & 1 & 0.5 & 0 & 0 \\
\hline University of Parma & 1 & 0.5 & 0.5 & 0.5 \\
\hline University of Pavia & 1 & 1 & 0.5 & 0 \\
\hline University of Perugia & 1 & 1 & 0.5 & 0.5 \\
\hline University of Pisa & 0.5 & 0 & 0.5 & 0.5 \\
\hline University of Rome La Sapienza & 0.5 & 0.5 & 0.5 & 0.5 \\
\hline University of Rome Tor Vergata & 1 & 1 & 0.5 & 0.5 \\
\hline University of Siena & 1 & 1 & 0 & 0.5 \\
\hline University of Turin & 1 & 1 & 0.5 & 1 \\
\hline University of Trieste & 1 & 1 & 0.5 & 1 \\
\hline University of Verona & 1 & 0.5 & 0.5 & 0.5 \\
\hline
\end{tabular}

Tab. 1 - Results obtained from the analysis of basic skills

TRANSVERSE SKILLS

University of Bari

University of Bologna

University of Cagliari

University of Campania

University of Catania

University of Catanzaro

University of Cattolica (Rome)

University of Ferrara

University of Florence

University of Genoa

University of Marche

University of Messina

University of Milan

University of Modena and Reggio Emilia

University of Naples

University of Padua

University of Palermo

University of Parma

University of Pavia

University of Perugia

University of Pisa

University of Rome La Sapienza

University of Rome Tor Vergata

University of Siena

University of Turin

University of Trieste

University of Verona

\begin{tabular}{|c|c|c|}
\hline MANAGEMENT AREA & INNOVATIVE AREA & RELATIONAL AREA \\
\hline 0 & 1 & 1 \\
\hline 1 & 1 & 1 \\
\hline 0 & 1 & 1 \\
\hline 1 & 1 & 1 \\
\hline 0 & 1 & 1 \\
\hline 1 & 1 & 1 \\
\hline 1 & 1 & 1 \\
\hline 0 & 1 & 1 \\
\hline 1 & 1 & 1 \\
\hline 1 & 1 & 1 \\
\hline 1 & 1 & 1 \\
\hline 1 & 1 & 1 \\
\hline 1 & 1 & 1 \\
\hline 1 & 1 & 1 \\
\hline 0 & 1 & 1 \\
\hline 0 & 1 & 1 \\
\hline 1 & 1 & 1 \\
\hline 1 & 1 & 1 \\
\hline 1 & 1 & 1 \\
\hline 1 & 1 & 1 \\
\hline 1 & 1 & 1 \\
\hline 1 & 1 & 1 \\
\hline 1 & 1 & 1 \\
\hline 1 & 1 & 1 \\
\hline 1 & 1 & 1 \\
\hline 1 & 1 & 1 \\
\hline 0 & 1 & 1 \\
\hline
\end{tabular}

Tab. 2 - Results obtained from the analysis of Comp and Tenze Transversal 


\begin{tabular}{|c|c|c|c|c|}
\hline $\begin{array}{l}\text { TRANSVERSAL TECHNICAL-PROFESSIONAL } \\
\text { COMPETENCE }\end{array}$ & MANAGEMENT & TRAINING & RESEARCH & ADVICE \\
\hline University of Bari & 0 & 0 & 0.5 & 1 \\
\hline University of Bologna & 0.5 & 0 & 0.5 & 1 \\
\hline University of Cagliari & 0 & 0 & 0 & 1 \\
\hline University of Campania & 0.5 & 0 & 0.5 & 1 \\
\hline University of Catania & 0.5 & 0 & 0.5 & 1 \\
\hline University of Catanzaro & 0 & 1 & 1 & 1 \\
\hline University of Cattolica (Rome) & 0.5 & 0 & 0.5 & 1 \\
\hline University of Ferrara & 0 & 0 & 0.5 & 1 \\
\hline University of Florence & 0.5 & 0 & 0.5 & 1 \\
\hline University of Genoa & 1 & 1 & 1 & 1 \\
\hline University of Marche & 0.5 & 0 & 0.5 & 1 \\
\hline University of Messina & 0.5 & 0 & 0.5 & 1 \\
\hline University of Milan & 1 & 1 & 1 & 1 \\
\hline University of Modena and Reggio Emilia & 1 & 1 & 0.5 & 1 \\
\hline University of Naples & 0 & 0 & 0 & 0 \\
\hline University of Padua & 0.5 & 0 & 1 & 1 \\
\hline University of Palermo & 0.5 & 0 & 0.5 & 1 \\
\hline University of Parma & 0.5 & 0 & 0.5 & 1 \\
\hline University of Pavia & 0.5 & 0 & 1 & 1 \\
\hline University of Perugia & 0.5 & 0 & 1 & 1 \\
\hline University of Pisa & 0 & 0 & 0.5 & 1 \\
\hline University of Rome La Sapienza & 0.5 & 0 & 1 & 1 \\
\hline University of Rome Tor Vergata & 0.5 & 0 & 1 & 1 \\
\hline University of Siena & 0 & 0 & 0 & 0 \\
\hline University of Turin & 1 & 0 & 1 & 1 \\
\hline University of Trieste & 1 & 1 & 1 & 1 \\
\hline University of Verona & 0 & 0 & 0 & 1 \\
\hline
\end{tabular}

Tab. 3 - Results obtained from the analysis of the Technical-Professional Transversal Skills

\begin{tabular}{|c|c|c|c|c|}
\hline $\begin{array}{l}\text { TECINCO PROFESSIONAL SKILLS } \\
\text { (SPECIFICATIONS) (1) }\end{array}$ & $\begin{array}{l}\text { LOGOPEDIC EVA- } \\
\text { LUATION AND BA- } \\
\text { LANCE } \\
\end{array}$ & & & \\
\hline $\begin{array}{l}\text { Assume objective and subjective in- } \\
\text { formation for the identification of the } \\
\text { rehabilitative needs of the person and } \\
\text { the community }\end{array}$ & $\begin{array}{l}\text { Formulate therapeutic } \\
\text { objectives referable } \\
\text { to the speech therapy } \\
\text { clinic }\end{array}$ & $\begin{array}{l}\text { Assess the } \\
\text { socio-envi- } \\
\text { ronmental } \\
\text { context }\end{array}$ & $\begin{array}{c}\text { Enable and rehabilitate patholo- } \\
\text { gies of the voice, word, oral and } \\
\text { written language, communicative } \\
\text { and cognitive disabilities and oral } \\
\text { functions }\end{array}$ & \\
\hline University of Bari & 1 & 1 & 0 & \\
\hline University of Bologna & 1 & 1 & 0 & \\
\hline University of Cagliari & 1 & 1 & 0 & \\
\hline University of Campania & 1 & 1 & 0 & \\
\hline University of Catania & 1 & 1 & 0 & \\
\hline University of Catanzaro & 1 & 1 & 0 & \\
\hline University of Cattolica (Rome) & 1 & 1 & 0 & \\
\hline University of Ferrara & 1 & 1 & 0 & \\
\hline University of Florence & 1 & 1 & 0 & \\
\hline University of Genoa & 1 & 1 & 0 & \\
\hline University of Marche & 1 & 1 & 0 & \\
\hline University of Messina & 1 & 1 & 0 & \\
\hline University of Milan & 1 & 1 & 0 & \\
\hline University of Modena and Reggio Emilia & 1 & 1 & 0 & \\
\hline University of Naples & 1 & 1 & 0 & \\
\hline University of Padua & 1 & 1 & 0 & \\
\hline University of Palermo & 1 & 1 & 0 & \\
\hline University of Parma & 1 & 1 & 0 & \\
\hline University of Pavia & 1 & 1 & 0 & \\
\hline University of Perugia & 1 & 1 & 0 & \\
\hline University of Pisa & 1 & 1 & 0 & \\
\hline University of Rome La Sapienza & 1 & 1 & 0 & \\
\hline University of Rome Tor Vergata & 1 & 1 & 0 & \\
\hline University of Siena & 1 & 1 & 0 & \\
\hline University of Turin & 1 & 1 & 0 & \\
\hline University of Trieste & 1 & 1 & 0 & \\
\hline University of Verona & 1 & 1 & 0 & 1 \\
\hline
\end{tabular}

Tab. 4 - Results obtained from the analysis of the Specific Technical Professional Skills: Speech Therapy Evaluation and Report 


\section{TECHNICAL PROFESSIONAL} SKILLS (SPECIFICATIONS) (2)

Define the rehabilitation program

University of Bari

University of Bologna

University of Cagliari

University of Campania

University of Catania

University of Catanzaro

University of Cattolica (Rome)

University of Ferrara

University of Florence

University of Genoa

University of Marche

University of Messina

University of Milan

University of Modena and Reggio Emilia

University of Naples

University of Padua

University of Palermo

University of Parma

University of Pavia

University of Perugia

University of Pisa

University of Rome La Sapienza

University of Rome Tor Vergata

University of Siena

University of Turin

University of Trieste

University of Verona
CARE AND

REHABILITATION

Perform the rehabilita- Check the effectiveness tion intervention

\begin{tabular}{|c|c|c|}
\hline $\begin{array}{c}\text { Check the effectiveness } \\
\text { of the intervention }\end{array}$ & $\begin{array}{c}\text { Addressing critical } \\
\text { situations }\end{array}$ & \\
\hline 1 & 0 & 0 \\
\hline 1 & 1 & 1 \\
\hline 1 & 1 & 0 \\
\hline 1 & 1 & 0 \\
\hline 1 & 0.5 & 0 \\
\hline 1 & 1 & 1 \\
\hline 1 & 0 & 0 \\
\hline 1 & 0 & 0 \\
\hline 1 & 1 & 1 \\
\hline 1 & 1 & 1 \\
\hline 1 & 1 & 1 \\
\hline 1 & 0 & 1 \\
\hline 1 & 1 & 1 \\
\hline 1 & 1 & 1 \\
\hline 1 & 0 & 0 \\
\hline 1 & 1 & 1 \\
\hline 1 & 1 & 1 \\
\hline 1 & 1 & 1 \\
\hline 1 & 1 & 0 \\
\hline 1 & 1 & 1 \\
\hline 0 & 0 & 0 \\
\hline 1 & 1 & 1 \\
\hline 1 & 1 & 1 \\
\hline 1 & 1 & 1 \\
\hline 1 & 1 & 1 \\
\hline 1 & 1 & 1 \\
\hline 1 & 0 & 0 \\
\hline
\end{tabular}

Tab. 5 - Results obtained from the analysis of the Specific Technical Professional Skills: Care and Rehabilitation

\section{TECHNICAL PROFESSIONAL SKILLS (SPECIFICATIONS) (3)}

PREVENTION

Preventing the effects of speech, speech, oral and written language, communicative and cognitive disabilities and oral functions

University of Bari

University of Bologna

University of Cagliari

University of Campania

University of Catania

University of Catanzaro

University of Cattolica (Rome)

University of Ferrara

University of Florence

University of Genoa

University of Marche

University of Messina

University of Milan

University of Modena and Reggio Emilia

University of Naples

University of Padua

University of Palermo

University of Parma

University of Pavia

University of Perugia

University of Pisa

University of Rome La Sapienza

University of Rome Tor Vergata

University of Siena

University of Turin

University of Trieste

University of Verona

\begin{tabular}{|c|c|}
\hline PREVENTION & \\
\hline $\begin{array}{l}\text { Promote health in the speech } \\
\text { therapy clinic }\end{array}$ & \\
\hline 0.5 & 1 \\
\hline 1 & 1 \\
\hline 1 & 1 \\
\hline 1 & 1 \\
\hline 1 & 0 \\
\hline 1 & 0 \\
\hline 1 & 1 \\
\hline 1 & 1 \\
\hline 1 & 1 \\
\hline 1 & 1 \\
\hline 1 & 1 \\
\hline 1 & 1 \\
\hline 1 & 1 \\
\hline 1 & 1 \\
\hline 1 & 1 \\
\hline 1 & 0 \\
\hline 1 & 1 \\
\hline 1 & 1 \\
\hline 1 & 1 \\
\hline 1 & 1 \\
\hline 0 & 1 \\
\hline 1 & 0 \\
\hline 1 & 1 \\
\hline 1 & 1 \\
\hline 1 & 1 \\
\hline 1 & 1 \\
\hline 1 & 1 \\
\hline
\end{tabular}

Tab. 6 - Results obtained from the analysis of the Specific Technical Professional Skills: Prevention. 


\begin{tabular}{|c|c|c|}
\hline TECHNICAL PROFESSIONAL SKILLS (SPECIFICATIONS) (4) & & \\
\hline & THERAPEUTIC EDUCATION & \\
\hline Carry out educational interventions in the speech therapy field & Establish a helping relationship & \\
\hline University of Bari & 1 & 1 \\
\hline University of Bologna & 1 & 1 \\
\hline University of Cagliari & 1 & 1 \\
\hline University of Campania & 1 & 0 \\
\hline University of Catania & 1 & 1 \\
\hline University of Catanzaro & 1 & 1 \\
\hline University of Cattolica (Rome) & 1 & 0 \\
\hline University of Ferrara & 1 & 1 \\
\hline University of Florence & 1 & 1 \\
\hline University of Genoa & 1 & 1 \\
\hline University of Marche & 1 & 1 \\
\hline University of Messina & 1 & 1 \\
\hline University of Milan & 1 & 1 \\
\hline University of Modena and Reggio Emilia & 1 & 1 \\
\hline University of Naples & 0.5 & 0 \\
\hline University of Padua & 1 & 1 \\
\hline University of Palermo & 1 & 1 \\
\hline University of Parma & 1 & 1 \\
\hline University of Pavia & 0 & 0 \\
\hline University of Perugia & 1 & 1 \\
\hline University of Pisa & 1 & 0 \\
\hline University of Rome La Sapienza & 1 & 1 \\
\hline University of Rome Tor Vergata & 1 & 1 \\
\hline University of Siena & 1 & 0 \\
\hline University of Turin & 1 & 1 \\
\hline University of Trieste & 1 & 1 \\
\hline University of Verona & 0 & 1 \\
\hline
\end{tabular}

Tab. 7 - Results obtained from the analysis of the Specific Technical Professional Skills: Therapeutic Education

\begin{tabular}{|c|c|c|c|c|c|c|c|c|}
\hline TOTAL SCORES & TOTAL $0-23$ & & & & & & & \\
\hline & $\begin{array}{c}\text { BASIC } \\
\text { SKILLS 0-4 }\end{array}$ & $\begin{array}{l}\text { TRANSVER- } \\
\text { SAL SKILLS } \\
0-3\end{array}$ & $\begin{array}{c}\text { TRANSVERSAL } \\
\text { TECHNICAL- } \\
\text { PROFESSIO- } \\
\text { NAL SKILLS 0-4 }\end{array}$ & \begin{tabular}{|c|} 
SPECIFIC \\
TECHNI- \\
CAL-PRO- \\
FESSIONAL \\
SKILLS \\
\end{tabular} & & & & \\
\hline $\begin{array}{l}\text { LOGOPEDIC EVALUA- } \\
\text { TION AND BALANCE 0-4 } \\
\end{array}$ & $\begin{array}{l}\text { CARE AND } \\
\text { REHABILI- } \\
\text { TATION 0-4 }\end{array}$ & $\begin{array}{l}\text { PREVEN- } \\
\text { TION } 0-2 \\
\end{array}$ & \begin{tabular}{|c|} 
TERAPEUTIC \\
EDUCATION A $0-2$ \\
\end{tabular} & & & & & \\
\hline University of Bari & 2.5 & 2 & 1.5 & 3 & 2 & 1.5 & 2 & 14.5 \\
\hline University of Bologna & 3.5 & 3 & 2 & 3 & 4 & 2 & 2 & 19.5 \\
\hline University of Cagliari & 0.5 & 2 & 1 & 3 & 3 & 2 & 2 & 13.5 \\
\hline University of Campania & 2.5 & 3 & 2 & 3 & 3 & 2 & 1 & 16.5 \\
\hline University of Catania & 3 & 2 & 2 & 3 & 2.5 & 1 & 2 & 15.5 \\
\hline University of Catanzaro & 2.5 & 3 & 3 & 3 & 4 & 1 & 2 & 18.5 \\
\hline University of Cattolica (Rome) & 2.5 & 3 & 2 & 3 & 2 & 2 & 1 & 15.5 \\
\hline University of Ferrara & 3 & 2 & 1.5 & 3 & 2 & 2 & 2 & 15.5 \\
\hline University of Florence & 3 & 3 & 2 & 3 & 4 & 2 & 2 & 19 \\
\hline University of Genoa & 3.5 & 3 & 4 & 3 & 4 & 2 & 2 & 21.5 \\
\hline University of Marche & 2.5 & 3 & 2 & 3 & 4 & 2 & 2 & 18.5 \\
\hline University of Messina & 2 & 3 & 2 & 3 & 3 & 2 & 2 & 17 \\
\hline University of Milan & 3 & 3 & 4 & 3 & 4 & 2 & 2 & 21 \\
\hline $\begin{array}{l}\text { University of Modena } \\
\text { and Reggio Emilia }\end{array}$ & 3 & 3 & 3.5 & 3 & 4 & 2 & 2 & 20.5 \\
\hline University of Naples & 3 & 2 & 0 & 3 & 2 & 2 & 0.5 & 12.5 \\
\hline University of Padua & 2.5 & 2 & 2.5 & 3 & 4 & 1 & 2 & 17 \\
\hline University of Palermo & 1.5 & 3 & 2 & 3 & 4 & 2 & 2 & 17.5 \\
\hline University of Parma & 2.5 & 3 & 2 & 3 & 4 & 2 & 2 & 18.5 \\
\hline University of Pavia & 2.5 & 3 & 2.5 & 3 & 3 & 2 & 1 & 17 \\
\hline University of Perugia & 3 & 3 & 2.5 & 3 & 4 & 2 & 1 & 18.5 \\
\hline University of Pisa & 1.5 & 3 & 1.5 & 3 & 2 & 1 & 1 & 13 \\
\hline $\begin{array}{l}\text { University of Rome } \\
\text { La Sapienza }\end{array}$ & 2 & 3 & 2.5 & 3 & 4 & 1 & 2 & 17.5 \\
\hline $\begin{array}{l}\text { University of Rome } \\
\text { Tor Vergata }\end{array}$ & 3 & 3 & 2.5 & 3 & 4 & 2 & 2 & 19.5 \\
\hline University of Siena & 2.5 & 3 & 0 & 3 & 4 & 2 & 1 & 15.5 \\
\hline University of Turin & 3.5 & 3 & 3 & 3 & 4 & 2 & 2 & 20.5 \\
\hline University of Trieste & 3.5 & 3 & 4 & 3 & 4 & 2 & 2 & 21.5 \\
\hline University of Verona & 2.5 & 2 & 1 & 3 & 2 & 2 & 1 & 13.5 \\
\hline
\end{tabular}

Tab. 8 - Results obtained from the analysis of skills: Total scores for each university 


\section{DISCUSSION}

This study aims to identify which skills are always present in the degree courses of Italian universities and which then become "specific" for the speech therapist profession. The results of this work are useful in order to standardize the framework of the speech therapist's skills; a need that derives from the lack of homogeneity present within the various training offers proposed by Italian universities. The advantage of having specific well-defined and above all homogeneous skills among the various universities in the national territory, as well as being an essential tool for clinical activity, is a demonstration of a suitable conduct to protect both the healthcare professional and the patient. The study of the SUA cards of the CDL in Speech Therapy present in Italy has shown that, with reference to the technical professional skills (i.e. the specific ones), only a few CDLs do not have these skills in their SUA card. In particular, the technical and professional skills always present in the SUA files are:

- With reference to the "Speech Therapist Assessment and Budget", the skills that are always present are: "to take objective and subjective information to identify the rehabilitative needs of the person and the community"; "Formulate therapeutic objectives referable to the speech therapy clinic"; "Enabling and rehabilitating pathologies of the voice, word, oral and written language, communication and cognitive disabilities and oral functions". The competence that is absent in all the SUA files regards knowing how to evaluate the socio-environmental context.

- With reference to the "Care and Rehabilitation" competence, in its specific sub-areas, it is noted: the competence "to define the rehabilitation program" is present in all the SUA files. While the competence defined "carry out the rehabilitation intervention" does not emerge in the SUA form of the CDL of Pisa. Regarding the skills "Check the effectiveness of the intervention" and "Addressing critical situations" there are discrepancies, in fact: the first is present in 19 CDL, absent in 7 CDL and partially present in only one CDL; while the second is absent in 10 USA files.

- With reference to the "Prevention" competence, the ever-present competences are: "to prevent the effects of pathologies of the voice, word, oral and written language, communicative and cognitive disabilities and oral functions". The competence "promoting health in the speech therapy clinic" is absent in 4 SUA files.

- With reference to the "Therapeutic Education" competence, in its specific sub-areas, it is noted that the competence "to carry out education interventions in the speech therapy field" is almost always present, with only two cases in which it is absent and one case in which it is partially present; the competence "to establish a helping relationship" is absent in 6 SUA form.

From the analysis of the scores, it emerges that the SUA cards with the most deficiencies, with reference to all the skills analyzed, are those that have achieved a score less than or equal to 16 . While the most complete SUA cards, that is, that have the highest number of skills, are those that have achieved a score equal to or greater than 19 . The maximum score that can be accrued, for all the skills analyzed, is 23 .
In the table below, the scores totaled in the Italian universities examined.

\begin{tabular}{|l|c|}
\hline CCDL in LOGOPEDIA & TTotal scores \\
\hline University of Genoa & 21.5 \\
\hline University of Trieste & 21.5 \\
\hline University of Milan & 21 \\
\hline University of Modena and Reggio Emilia & 20.5 \\
\hline University of Turin & 20.5 \\
\hline University of Bologna & 19.5 \\
\hline University of Rome Tor Vergata & 19.5 \\
\hline University of Florence & 19 \\
\hline University of Catanzaro & 18.5 \\
\hline University of Marche & 18.5 \\
\hline University of Parma & 18.5 \\
\hline University of Perugia & 18.5 \\
\hline University of Palermo & 17.5 \\
\hline University of Rome La Sapienza & 17.5 \\
\hline University of Messina & 17 \\
\hline University of Padua & 17 \\
\hline University of Pavia & 17 \\
\hline University of Campania & 16.5 \\
\hline University of Catania & 15.5 \\
\hline University of Cattolica (Rome) & 15.5 \\
\hline University of Ferrara & 15.5 \\
\hline University of Siena & 15.5 \\
\hline University of Bari & 14.5 \\
\hline University of Cagliari & 13.5 \\
\hline University of Verona & 13.5 \\
\hline University of Pisa & 13 \\
\hline University of Naples & 12.5 \\
\hline
\end{tabular}

Tab. 9 - Scores scored in the Italian universities examined.

An analysis of the scores accrued in relation to specific technical and professional skills only, showed that as many as 11 SUA cards have scored 11 out of a maximum of 12 . Only 6 SUA cards have scored less than or equal to 9 .

\begin{tabular}{|l|c|}
\hline CDL IN LOGOPEDIA & $\begin{array}{c}\text { Specific } \\
\text { technical- } \\
\text { professional } \\
\text { skills scores }\end{array}$ \\
\hline University of Bologna & 11 \\
\hline University of Florence & 11 \\
\hline University of Genoa & 11 \\
\hline University of Marche & 11 \\
\hline University of Milan & 11 \\
\hline University of Modena and Reggio Emilia & 11 \\
\hline University of Palermo & 11 \\
\hline University of Parma & 11 \\
\hline University of Rome Tor Vergata & 11 \\
\hline University of Turin & 11 \\
\hline University of Trieste & 11 \\
\hline University of Cagliari & 10 \\
\hline University of Catanzaro & 10 \\
\hline University of Messina & 10 \\
\hline University of Padua & 10 \\
\hline University of Perugia & 10 \\
\hline University of Rome La Sapienza & 10 \\
\hline University of Siena & 10 \\
\hline University of Campania & 9 \\
\hline University of Ferrara & 9 \\
\hline University of Pavia & 9 \\
\hline University of Bari & 8.5 \\
\hline University of Catania & 8.5 \\
\hline University of Cattolica (Rome) & 8 \\
\hline University of Verona & 7.5 \\
\hline University of Naples & 7 \\
\hline University of Pisa & \\
\hline & \\
\hline
\end{tabular}

Tab. 10 - Scores scored in Italian universities relating only to specific technical professional skills 


\begin{tabular}{|c|c|c|}
\hline REGION & CDL in LOGOEPDIA & $\begin{array}{l}\text { Total } \\
\text { scores }\end{array}$ \\
\hline Abruzzo & not present & NR \\
\hline$\overline{\text { Basilicata }}$ & not present & NR \\
\hline Calabria & University of Catanzaro & 18.5 \\
\hline \multirow{2}{*}{$\underline{\text { Campania }}$} & University of Campania & 16.5 \\
\hline & University of Naples & 12.5 \\
\hline \multirow{4}{*}{ Emilia Romagna } & University of Modena and Reggio Emilia & 20.5 \\
\hline & University of Bologna & 19.5 \\
\hline & University of Parma & 18.5 \\
\hline & University of Ferrara & 15.5 \\
\hline Friuli Venezia Giulia & University of Trieste & 21.5 \\
\hline \multirow{3}{*}{$\underline{\text { Lazio }}$} & University of Rome Tor Vergata & 19.5 \\
\hline & University of Rome La Sapienza & 17.5 \\
\hline & University of Cattolica (Rome) & 15.5 \\
\hline Liguria & University of Genoa & 21.5 \\
\hline \multirow[b]{2}{*}{$\underline{\text { Lombardy }}$} & University of Milan & 21 \\
\hline & University of Pavia & 17 \\
\hline Marche & University of Marche & 18.5 \\
\hline Molise & not present & NR \\
\hline Piedmont & University of Turin & 20.5 \\
\hline Puglia & University of Bari & 14.5 \\
\hline Sardinia & University of Cagliari & 13.5 \\
\hline \multirow{3}{*}{$\underline{\text { Sicily }}$} & University of Palermo & 17.5 \\
\hline & University of Messina & 17 \\
\hline & University of Catania & 15.5 \\
\hline \multirow{3}{*}{$\underline{\text { Tuscany }}$} & University of Florence & 19 \\
\hline & University of Siena & 15.5 \\
\hline & University of Pisa & 13 \\
\hline Trentino Alto Adige & not present & NR \\
\hline Umbria & University of Perugia & 18.5 \\
\hline Valle d'Aosta & not present & NR \\
\hline \multirow{2}{*}{$\underline{\text { Veneto }}$} & University of Padua & 17 \\
\hline & University of Verona & 13.5 \\
\hline
\end{tabular}

Tab. 11

The research also showed that in 7 Italian regions there are more than one CDL in speech therapy. In particular:

- in Emilia-Romagna there are 4 CDLs in Speech Therapy;

- in Lazio, Sicily and Tuscany there are 3 CDLs in Speech Therapy;

- $\quad$ in Campania, Lombardy and Veneto there are 2 CDLs in Speech Therapy.

In Abruzzo, Basilicata, Molise, Trentino Alto Adige and Valle d'Aosta there is no CDL in Speech Therapy. In the following table (Table 11) it is also possible to appreciate the score variations in the regions where there are more than one CDL in Speech Therapy.

The following table (Table 12) shows the scores, both total and relating to specific technical-professional skills, of the CDL in Speech Therapy present on the national territory divided by geographical area (Northern Italy, Central Italy and Southern Italy). The 27 CDLs in Speech Therapy in Italy are divided as follows: 11 in Northern Italy, 8 in Central Italy and 8 in Southern Italy. Looking at the graph, it can be seen that the SUA cards of the CDL in Logopedia that have achieved a higher score, both for the total scores and those related to specific technical and professional skills, are more widely distributed in the Northern Italy area.

Analysis of the data shows that the average for the total scores is:

- 18.72 for Northern Italy;

- $\quad 17,13$ for Central Italy;

- 15.69 for Southern Italy.

While, the average for the scores attributed to specific technical and professional skills is:

- 10.27 for Northern Italy;

- 9.75 for Center Italy;

- 9.31 for Southern Italy.

\section{CONCLUSIONS}

This work aims to provide a picture of the specific skills common to the training objectives of the Degree Courses in Speech Therapy, identified in the 2017/2018 academic year. From what emerged at national level, it is clear that: basic skills were insufficient as regards the areas of labor law and company organization; transversal skills were instead well defined and almost always present; the transversal technical-professional skills appeared insufficient for the areas of management and research; Among the specific technical and professional skills, the competence on "assessment of the socio-environmental context" is particularly lacking. The need to standardize the skills plan is fundamental in terms of specific training, in order to guarantee all the students of the Logopedia CDL the skills necessary for the speech therapy clinical exercise. High evidence of the technical-professional skills within the educational systems appears fundamental for the creation of professionals who are able to operate in their specific sector with efficacy, efficiency, responsibility and autonomy, interacting with other professional figures, from whom they must know how to stand out and with whom they will have to collaborate to safeguard and improve the health of citizens. What has been said has emerged both at a territorial and at a national level: the non-homogeneities detected inevitably lead to the proliferation of professionals with adequate skills on some fronts but incomplete on others, thus not guaranteeing Italian citizens the same quality of treatment throughout the territory national. It is therefore desirable that healthcare professionals fulfill complete and homogeneous skills, which should not be acquired only with respect to the geographical area of relevance, but also at national and institutional level. This would represent a real advantage both for the protection of the patient and for the healthcare professional: the advantage of having specific, well-defined and uniform skills, related to one's profession, essential for clinical activity. In light of what emerged from the results of this study, it is hoped that the publication of this research will allow the universities concerned to follow up on the current state of the CDL in speech therapy, so as to guarantee common and homogeneous training courses throughout the national territory. 


\begin{tabular}{|c|c|c|c|}
\hline & CDL in LOGOPEDIA & Total scores & $\begin{array}{c}\text { Specific technical- } \\
\text { professional skills } \\
\text { scores }\end{array}$ \\
\hline \multirow{11}{*}{$\begin{array}{l}\text { NORTHERN } \\
\text { ITALY }\end{array}$} & University of Bologna & 19.5 & 11 \\
\hline & University of Ferrara & 15.5 & 9 \\
\hline & University of Genoa & 21.5 & 11 \\
\hline & University of Milan & 21 & 11 \\
\hline & $\begin{array}{l}\text { University of Modena and } \\
\text { Reggio Emilia }\end{array}$ & 20.5 & 11 \\
\hline & University of Padua & 17 & 10 \\
\hline & University of Parma & 18.5 & 11 \\
\hline & University of Pavia & 17 & 9 \\
\hline & University of Turin & 20.5 & 11 \\
\hline & University of Trieste & 19.5 & 11 \\
\hline & University of Verona & 15.5 & 8 \\
\hline \multirow{8}{*}{$\begin{array}{l}\text { CENTER OF } \\
\text { ITALY }\end{array}$} & Catholic University (Rome) & 15.5 & 8 \\
\hline & University of Florence & 19 & 11 \\
\hline & University of Marche & 18.5 & 11 \\
\hline & University of Perugia & 18.5 & 10 \\
\hline & University of Pisa & 13 & 7 \\
\hline & $\begin{array}{l}\text { University of Rome La } \\
\text { Sapienza }\end{array}$ & 17.5 & 10 \\
\hline & $\begin{array}{l}\text { University of Rome Tor } \\
\text { Vergata }\end{array}$ & 19.5 & 11 \\
\hline & University of Siena & 15.5 & 10 \\
\hline \multirow{8}{*}{$\begin{array}{l}\text { SOUTHERN } \\
\text { ITALY }\end{array}$} & University of Bari & 14.5 & 8.5 \\
\hline & University of Cagliari & 13.5 & 10 \\
\hline & University of Campania & 16.5 & 9 \\
\hline & University of Catania & 15.5 & 8.5 \\
\hline & University of Catanzaro & 18.5 & 10 \\
\hline & University of Messina & 17 & 10 \\
\hline & University of Naples & 12.5 & 7.5 \\
\hline & University of Palermo & 17.5 & 11 \\
\hline
\end{tabular}

Tab. 12

\section{REFERENCES}

1. Regini, M. (2014). La riforma universitaria nel quadro dei sistemi di governance europei. Firenze University Press

2. Triventi, M. (2012). Sistemi universitari comparati. Riforme, assetti istituzionali e accessibilità agli studenti. Mondadori Bruno.

3. Gaveglio, I., \& Vernero, I. (2001) Il logopedista. Profilo di una professione. Omega.

4. Vernero, I. \& Schindler, O. (2012) Storia della logopedia. Springer Verlag.

5. Legge 11 gennaio 2018, n. 3 "Delega al Governo in materia di sperimentazione clinica di medicinali nonché' disposizioni per il riordino delle professioni sanitarie e per la dirigenza sanitaria del Ministero della salute".

6. Legge 30 dicembre 2010, n. 240 "Norme in materia di organizzazione delle Università, di personale accademico e reclutamento, nonché delega al Governo per incentivare la qualità e l'efficienza del sistema universitario".

7. Decreto Legislativo 27 gennaio 2012, n. 19 "Valorizzazione dell'efficienza delle Università e conseguente introduzione di meccanismi premiali nella distribuzione di risorse pubbliche sulla base di criteri definiti ex ante anche mediante la previsione di un sistema di accreditamento periodico delle Università e la valorizzazione della figura dei ricercatori a tempo indeterminato non confermati al primo anno di attività, a norma dell'articolo 5, comma 1, lettera a), della legge 30 dicembre 2010, n. 240".

8. Decreto Ministeriale del 30 gennaio 2013, n.47.

9. Decreto Ministeriale del 23 dicembre 2013, n.1059.

10. Decreto Ministeriale del 12 dicembre 2016, n. 987.

11. DM 14 settembre 1994, n. 742 "Regolamento concernente l'individuazione della figura e del relativo profilo professionale del logopedista". 